\section{Research Article}

Accepted: 30-12-2020

To Cite: Meyvacı E, Öztürk T, Savaş B. 2021. Syntheses and characterizations of poly( $\varepsilon$-caprolactone-b-ethylene glycol methyl ether) block copolymers via ring-opening polymerization and "click" chemistry. Journal of the Institute of Science and Technology, 11(2): 1329-1340.

\title{
Syntheses And Characterizations Of Poly(E-Caprolactone-b-Ethylene Glycol Methyl Ether) Block Copolymers Via Ring-Opening Polymerization And "Click" Chemistry
}

\author{
Ergül MEYVACI ${ }^{1}$, Temel ÖZTÜRK ${ }^{1 *}$, Bedrettin SAVAŞ ${ }^{2}$
}

\begin{abstract}
Poly( $\varepsilon$-caprolactone-block-ethylene glycol methyl ether) [poly(RCL-b-mEG)] block copolymers were synthesized by "click" chemistry of polyethylene glycol methyl ether propargyl (mPEG-propargyl) and poly(e-caprolactone) azido (RPCL- $\left.\mathrm{N}_{3}\right)$. Thus, mPEG-propargyl was acquired through the reaction of polyethylene glycol methyl ether with propargyl bromine. 2-[2-(2-Azidoethoxy)ethoxy]ethanol $\left(\mathrm{N}_{3} \mathrm{Ol}\right)$ was synthesized by using 2-[2-(2-chloroethoxy)ethoxy]ethanol and sodium azide. Synthesis of RPCL-N 3 was acquired using ROP of e-caprolactone and $\mathrm{N}_{3}$ ol. By using mPEG-propargyl and RPCL- $\mathrm{N}_{3}$, poly(RCL-b-mEG) block copolymers were obtained via "click" chemistry. The monofunctional homopolymers in the study were utilized for the syntheses of poly(RCL-b-mEG) block copolymers. The outputs were identified by scanning electron microscopy, ${ }^{1} \mathrm{H}$-nuclear magnetic resonance spectroscopy, differential scanning calorimetry, thermogravimetric analysis, Fourier-transform infrared spectroscopy, gel permeation chromatography, and dynamic light scattering instruments. The spectroscopic and thermal analysis of the block copolymers monitor that the copolymers were built through combination of ROP and "click" chemistry.
\end{abstract}

Keywords: Block copolymer, "click" chemistry, polyethylene glycol methyl ether propargyl, poly( $\varepsilon$ caprolactone) azido, ring-opening polymerization, 2-[2-(2-azidoethoxy)ethoxy]ethanol.

${ }^{1}$ Ergül MEYVACI (Orcid ID: 0000-0003-3530-1316), Temel ÖZTÜRK (Orcid ID: 0000-0002-7856-9809), Giresun University, Department of Chemistry, Giresun, Turkey

${ }^{2}$ Bedrettin SAVAŞ (Orcid ID: 0000-0002-6620-5493), Kafkas University, Kars Vocational School, Kars, Turkey

*Corresponding Author: Temel ÖZTÜRK. E-mail: temel.ozturk@ giresun.edu.tr 


\section{INTRODUCTION}

Polyethylene glycol (PEG) which is one of the most used hydrophilic segment (Adams, et al., 2003) is preferred in block copolymers possibly because it has got unique biocompatible properties (Çatıker, et al., 2020). PEG-based polymers are desirable materials of biomedical, industrial, and chemicals applications thanks to PEG's unique features (Erciyes et al., 1992; Adams, et al., 2003; Riess, 2003; Gacal, et al., 2006; Öztürk and Hazer, 2010; Çatıker, et al., 2020). Syntheses of block or graft copolymers were fullfilled because of their enuque properties (Ruzette and Leibler, 2005; Öztürk, et al., 2011; Altintas et al., 2011; Bolton and Rzayev, 2012; Öztürk, Kayğın, et al., 2016; Öztürk, Cakmak et al., 2019; Çatıker, et al., 2019; Bağlan et al., 2018; Öztürk, Savaş, et al., 2020). The capability of amphiphilic block copolymers is owing to their chemical composition, which is described by a hydrophilic block chemically related to a hydrophobic block (Çatıker, et al., 2020). The ring-opening polymerization (ROP) technique was firstly carried out by Carothers et al. for lactones, cyclic anhydrides and carbonates (Hizal, et al., 2005; Coulembier, et al., 2006; Çatıker, et al., 2020;). ROP technique was widely used in the syntheses of new types of copolymers (Coulembier, et al., 2006; Göktaş et al., 2014; Öztürk, Yavuz, et al., 2016; Öztürk, et al., 2018). The applications in "click" chemistry have been examined (Moses and Moorhouse, 2007; Xu et al., 2007; Altıntas and Tunca, 2011; Tunca, 2013; Xi et al., 2014; Zhu et al., 2015; Öztürk and Meyvac1 2017; Öztürk, et al., 2019) since "click" chemistry was presented by Sharpless et al. (Kolb et al., 2001) in 2001. Recently, "click" chemistry technique has been developed in the synthesis of polymers by increasing its place in science (Binder and Sachsenhofer, 2007; Barner-Kowollik et al., 2011; Şanal et al., 2017; Öztürk and Cavicchi, 2018; Tunca, 2018; Öztürk and Yörümez, 2020).

This paper demonstrates syntheses of poly( $\varepsilon$-caprolactone-block-ethylene glycol methyl ether) [poly(RCL-b-mEG)] block copolymers through ROP and "click" chemistry methods. Firstly, synthesis of polyethylene glycol methyl ether propargyl (mPEG-propargyl) obtained by reaction of polyethylene glycol methyl ether with 5,000 Da (mPEG-5000) and propargyl bromine was presented. Then, 2-[2-(2azidoethoxy)ethoxy]ethanol $\left(\mathrm{N}_{3} \mathrm{Ol}\right)$ was synthesized by reaction of 2-[2-(2-chloroethoxy)ethoxy]ethanol and $\mathrm{NaN}_{3}$ as ref. (Baker et al., 2013). After that, poly( $\varepsilon$-caprolactone) azido (RPCL-N $\mathrm{N}_{3}$ ) was acquired using $\varepsilon$-caprolactone (CL) and $\mathrm{N}_{3}$ ol by ROP technic. Lastly, RPCL-N 3 and mPEG-propargyl were utilized by "click" chemistry to obtain poly(RCL-b-mEG) block copolymers. Furthermore, the product characterization was provided in detail.

\section{MATERIALS AND METHODS}

\section{Materials}

Sigma-Aldrich supplied $\quad \operatorname{tin}(\mathrm{II}) \quad$ 2-ethylhexanoate $\quad\left[\operatorname{Sn}(\mathrm{Oct})_{2}\right], \quad$ 2-[2-(2chloroethoxy)ethoxy]ethanol, $\mathrm{NaN}_{3}$, mPEG-5000, propargyl bromine, chloroform, $N, N, N^{\prime}, N^{\prime}, N^{\prime \prime}-$ pentamethyldiethylenetriamine (PMDETA), $\varepsilon$-caprolactone (CL), CuBr. Triethylamine (TEA), methanol, diethyl ether were obtained from Merck, Kimetsan, and Carlo Erba Reagent, respectively.

\section{Instrumentation}

Records of ${ }^{1} \mathrm{H}-\mathrm{NMR}$ spectra were obtained by ultra-long hold time 400 NMR spectrometers called as Bruker Ultra Shield Plus. FT-IR were obtained by Jasco FT/IR 6600 FT-IR spectrometer. Molecular weight and dispersity were studied by HPLC/GPC-Shimadzu RID-10A GPC instrument with THF at 40 ${ }^{\circ} \mathrm{C}$ through Refractive Index Detector. A calibration curve was generated with polystyrene standards of low dispersity ( $\mathrm{Mw}=1490,2500,5480,9500,20800$ and $53500 \mathrm{Da})$. SEM displays were taken by using a Hitachi SU 1510 electron microscope. DSC measurement was obtained by Hitachi DSC 7000 series 
thermal analysis system under $\mathrm{N}_{2}$ gas. Dynamic light scattering (DLS) instrument was Malvern Zetasizer Nano Series Nano-ZS with Insmark IR120 model refractometer (solvent: DMF; concentration: $1 \mathrm{mg} / \mathrm{mL}$, $0.5 \mathrm{mg} / \mathrm{mL}$, and $0.25 \mathrm{mg} / \mathrm{mL}$; temperature: $20^{\circ} \mathrm{C} ; \lambda=633 \mathrm{~nm}$ ). TGA were obtained by a Seiko II Exstar 6000 model instrument.

\section{Synthesis of polyethylene glycol methyl ether propargyl (mPEG-propargyl)}

Typically, $4.087 \mathrm{~g}(0.81 \mathrm{mmol})$ of mPEG-5000 and $0.110 \mathrm{~g}(1.08 \mathrm{mmol})$ of TEA in $10 \mathrm{~mL}$ of $\mathrm{CHCI}_{3}$ was poured into a $250 \mathrm{~mL}$ clear flask with a $\mathrm{N}_{2}$ input and cooled off to below $0{ }^{\circ} \mathrm{C} .0 .126 \mathrm{~g}(1.05$ mmol) of propargyl bromine in $3 \mathrm{~mL}$ of $\mathrm{CHCI}_{3}$ was put into this solution by a dropping funnel during 20 minutes. The solution was blended for 30 minutes below $0{ }^{\circ} \mathrm{C}$. Next, the content slowly reached to ambient temperature. 24 hours later, $\mathrm{CHCI}_{3}$ was to some extend vaporized. The residue was precipitated in cold excess diethyl ether. Following decantation, mPEG-propargyl was made dry at $40{ }^{\circ} \mathrm{C}$ in vacuum oven during 4 days. mPEG-propargyl output was obtained gravimetrically. The gravimetric yield was $98.79 \mathrm{wt} \%$ (4.162 g).

\section{Synthesis of 2-[2-(2-azidoethoxy)ethoxy]ethanol (N3ol)}

$\mathrm{N}_{3} \mathrm{ol}$ was synthesized as ref. (Baker et al., 2013). For instance, $2.227 \mathrm{~g}(0.01 \mathrm{mmol})$ of 2-[2-(2chloroethoxy)ethoxy]ethanol, $4.039 \mathrm{~g}(0.06 \mathrm{mmol})$ of $\mathrm{NaN}_{3}, 60 \mathrm{~mL}$ of distilled water were poured into a $250 \mathrm{~mL}$ clear flask. Flask was dip in oil bath which was fixed at $70{ }^{\circ} \mathrm{C}$ on hot plate for reflux. After 22 hours, the reaction mixture was put into extraction process with diethyl ether $(80 \mathrm{~mL} \times 3)$. The organic layer was made dry on $\mathrm{MgSO}_{4}$ and was vaporized until its drying to obtain $\mathrm{N}_{3} \mathrm{Ol}$ as a clear oil. Product yield was defined gravimetrically $(0.475 \mathrm{~g}, 24.33 \mathrm{wt} \%)$.

\section{Synthesis of poly(\&-caprolactone) azido (RPCL-N3) through ROP}

Poly( $\varepsilon$-caprolactone) azido which was presented RPCL-N 3 was achieved by ROP as procedures below: $4.100 \mathrm{~g}(0.041 \mathrm{~mol})$ of $\mathrm{CL}, 0.475 \mathrm{~g}(0.002 \mathrm{~mol})$ of $\mathrm{N}_{3} \mathrm{ol}, \mathrm{Sn}(\mathrm{Oct})_{2}(1-2$ drops $)$ were placed separately in glass tube, then, $\mathrm{N}_{2}$ gas was injected into tube for $5 \mathrm{~min}$. Tube was covered with rubber septum, put into oil bath at $120^{\circ} \mathrm{C}$ during 24 hours. After 24 hours, the content of the tube was mixed into cold excess diethyl ether for separation of RPCL-N ${ }_{3}$. The product was placed in a fridge during a night. Following decantation, the polymer was made dry at $40{ }^{\circ} \mathrm{C}$ under vacuum during 4 days. Yield of RPCL-N 3 was $85.51 \mathrm{wt} \%$ (3.867 g).

Table 1. Syntheses of poly(RCL-b-mEG) copolymers by "click" chemistry.

\begin{tabular}{lllllllc}
\hline & & & & & & \multicolumn{2}{c}{ Decomposition } \\
\cline { 6 - 8 } Code & $\begin{array}{l}\text { mPEG- } \\
\text { propargyl }(\mathrm{g})\end{array}$ & $\begin{array}{l}\text { RPCL-N } \\
(\mathrm{g})\end{array}$ & $\begin{array}{l}\text { Yield } \\
(\mathrm{g})\end{array}$ & $\begin{array}{l}\text { Yield } \\
(\mathrm{wt} \%)\end{array}$ & $\begin{array}{l}\text { Mw } \\
\left(\mathrm{g} . \mathrm{mol}^{-1}\right)\end{array}$ & $\mathrm{Td} 1$ & $\mathrm{~T}$ \\
\hline E-1 & 0.243 & 0.144 & 0.303 & 78.15 & 9,160 & 306 & 411 \\
E-2 & 0.242 & 0.244 & 0.455 & 93.72 & 6,510 & 340 & 399 \\
E-3 & 0.247 & 0.344 & 0.445 & 75.25 & 10,400 & 334 & 399 \\
E-4 & 0.245 & 0.417 & 0.550 & 83.12 & 8,620 & 343 & 394 \\
\hline
\end{tabular}

Temperature: $35^{\circ} \mathrm{C}$, time: 48 hours, chloroform: $3 \mathrm{~mL}$, copper(I) bromide: $0.003 \mathrm{~g}, \quad$ PMDETA: $0.008 \mathrm{~g}$.

\section{Synthesis of poly(E-caprolactone-block-ethylene glycol methyl ether) [poly(RCL-b-mEG)] by "click" chemistry}

The amounts of the materials which were utilized in block copolymerization were presented in Table 1. mPEG-propargyl, RPCL-N 3 , PMDETA, CuBr, chloroform was placed into glass tubes and then $\mathrm{N}_{2}$ was injected into tube for $5 \mathrm{~min}$. Tubes were placed in oil bath at $35{ }^{\circ} \mathrm{C}$ on a magnetic stirrer. 48 hours later, the contents of the tubes were strained out. $\mathrm{CuBr}$ left was removed with small alumina 
columns from the block copolymers. The mixtures were poured into excess methanol for separation of precipitated poly(RCL-b-mEG) copolymers. The copolymers were dried in vacuum oven at ambient temperature during 4 days. Products were determined gravimetrically as shown in Table 1 .

\section{RESULTS AND DISCUSSION}

\section{Synthesis of mPEG-propargyl}

mPEG-propargyl was acquired as white solid by mPEG-5000 $\left({ }^{1} \mathrm{H}-\mathrm{NMR}\right.$ for mPEG-5000: $3.5 \mathrm{ppm}$ for $-\mathrm{OCH}_{2}, 2.5 \mathrm{ppm}$ for $\left.-\mathrm{O} \underline{\mathrm{H}}\right)$. Reaction pathway is included on the first line of Scheme 1 for the synthesis of mPEG-propargyl. Figure 1.A shows FT-IR spectrum of mPEG-propargyl. The successful propargylation of mPEG-5000 is provided with the creation of acetylenic band at about $3150 \mathrm{~cm}^{-1} .{ }^{1} \mathrm{H}$ NMR spectrum of mPEG-propargyl in Figure 2A displayed peaks at $3.5 \mathrm{ppm}$ for $-\mathrm{OC}_{2}$ of $\mathrm{mPEG}-5000$, $3.4 \mathrm{ppm}$ for $-\mathrm{OC} \underline{\mathrm{H}}_{2}$ of propargyl group linked mPEG-5000 unit, $1.2 \mathrm{ppm}$ for $-\mathrm{C} \equiv \mathrm{C} \underline{\mathrm{H}}$. Peak at $1.2 \mathrm{ppm}$ for $-\mathrm{C} \equiv \mathrm{C} \underline{\mathrm{H}}$ in ${ }^{1} \mathrm{H}-\mathrm{NMR}$ proved which $\mathrm{mPEG}$-propargyl was successfully acquired.

$$
\begin{aligned}
& \mathrm{HO}\left(\mathrm{CH}_{2} \mathrm{CH}_{2} \mathrm{O}\right)_{\mathbf{n}} \mathrm{CH}_{3}+\mathrm{BrCH}_{2} \mathrm{C} \equiv \mathrm{CH} \underset{+\mathrm{TEA}}{\stackrel{25^{\circ} \mathrm{C}}{\longrightarrow}} \mathrm{HC} \equiv \mathrm{CCH}_{2}-\mathrm{O}+\mathrm{CH}_{2} \mathrm{CH}_{2} \mathrm{O}+\mathrm{CH}_{\mathbf{n}} \\
& \begin{array}{lll}
\text { mPEG-5000 propargyl bromine } & \begin{array}{l}
-\mathrm{HBr}^{2} \\
\text { in } \mathrm{CHCl}_{3}
\end{array} \quad \text { mPEG-propargyl }
\end{array} \\
& \mathrm{Cl}-\mathrm{CH}_{2} \mathrm{CH}_{2}-\mathrm{O}-\mathrm{CH}_{2} \mathrm{CH}_{2}-\mathrm{O}-\mathrm{CH}_{2} \mathrm{CH}_{2}-\mathrm{OH}+\mathrm{NaN}_{3} \underset{\text { in }{ }^{\circ} \mathrm{H}_{2} \mathrm{O}}{\longrightarrow}-\mathrm{N}_{3}-\mathrm{CH}_{2} \mathrm{CH}_{2}-\mathrm{O}-\mathrm{CH}_{2} \mathrm{CH}_{2}-\mathrm{O}-\mathrm{CH}_{2} \mathrm{CH}_{2}-\mathrm{OH} \\
& \text { 2-[2-(2-chloroethoxy)ethoxy]ethanol sodium azide } \quad \mathrm{N}_{3} \mathrm{Ol} \\
& \stackrel{\mathrm{O}}{\mathrm{O}}+\mathrm{N}_{3}\left(\mathrm{CH}_{2} \mathrm{CH}_{2} \mathrm{O}\right)_{2} \mathrm{CH}_{2} \mathrm{CH}_{2} \mathrm{OH} \frac{120^{\circ} \mathrm{C}}{\mathrm{Sn}(\mathrm{Oct})_{2}}-\mathrm{H}\left(\mathrm{O}\left(\mathrm{CH}_{2}\right)_{5} \stackrel{\mathrm{O}}{\mathrm{I}}+\mathrm{f}_{\mathbf{p}} \mathrm{OCH}_{2} \mathrm{CH}_{2}\left(\mathrm{OCH}_{2} \mathrm{CH}_{2}\right)_{2} \mathrm{~N}_{3}\right. \\
& \text { CL } \\
& \text { RPCL- } \mathrm{N}_{3}
\end{aligned}
$$

Scheme 1. Reaction schemes for syntheses of mPEG-propargyl, $\mathrm{N}_{3} \mathrm{Ol}$, and RPCL-N 3

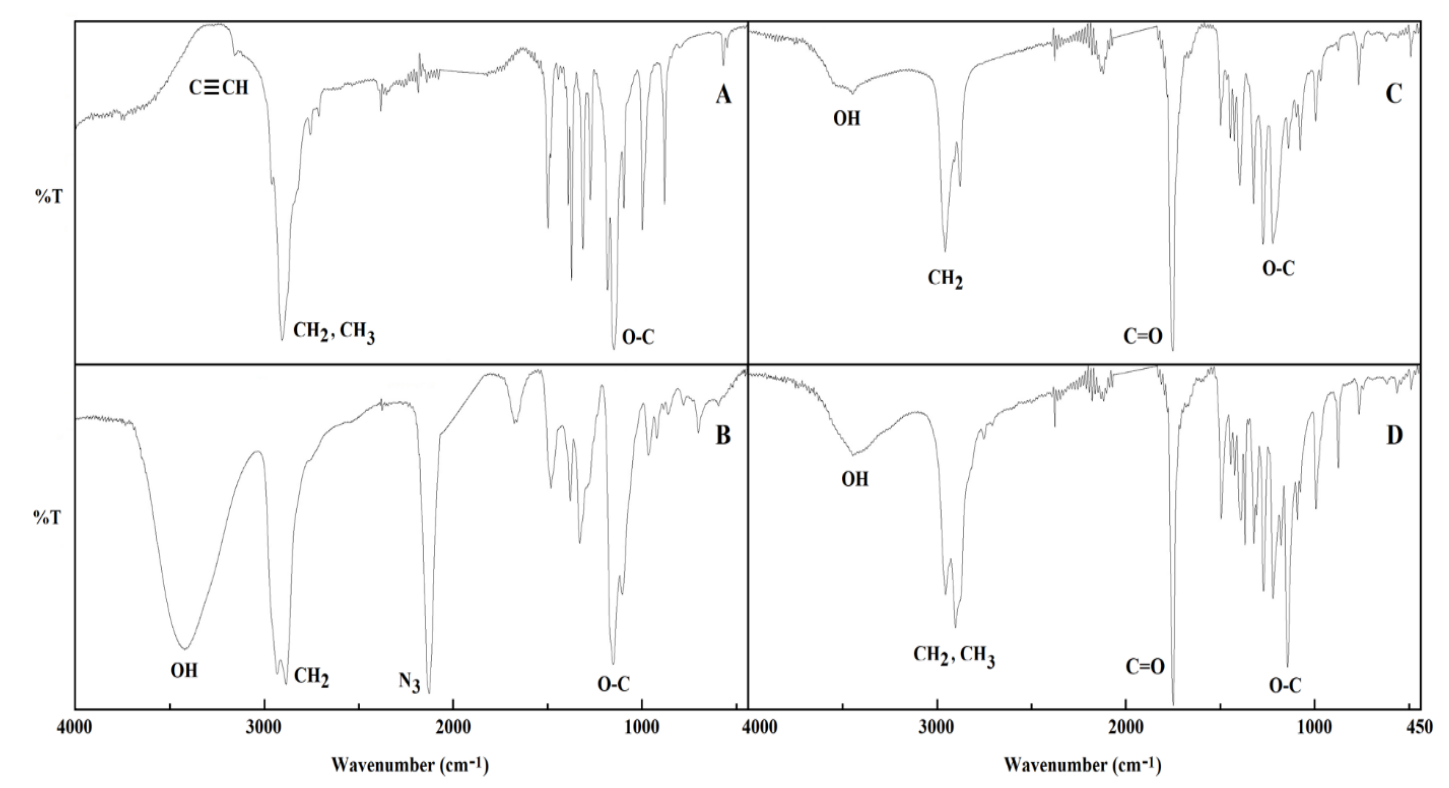

Figure 1. FT-IR spectra of mPEG-propargyl (A), $\mathrm{N}_{3} \mathrm{Ol}$ (B), RPCL-N 3 (C), and poly(RCL-b-mEG) block copolymer (D) (E-3 in Table 1). 


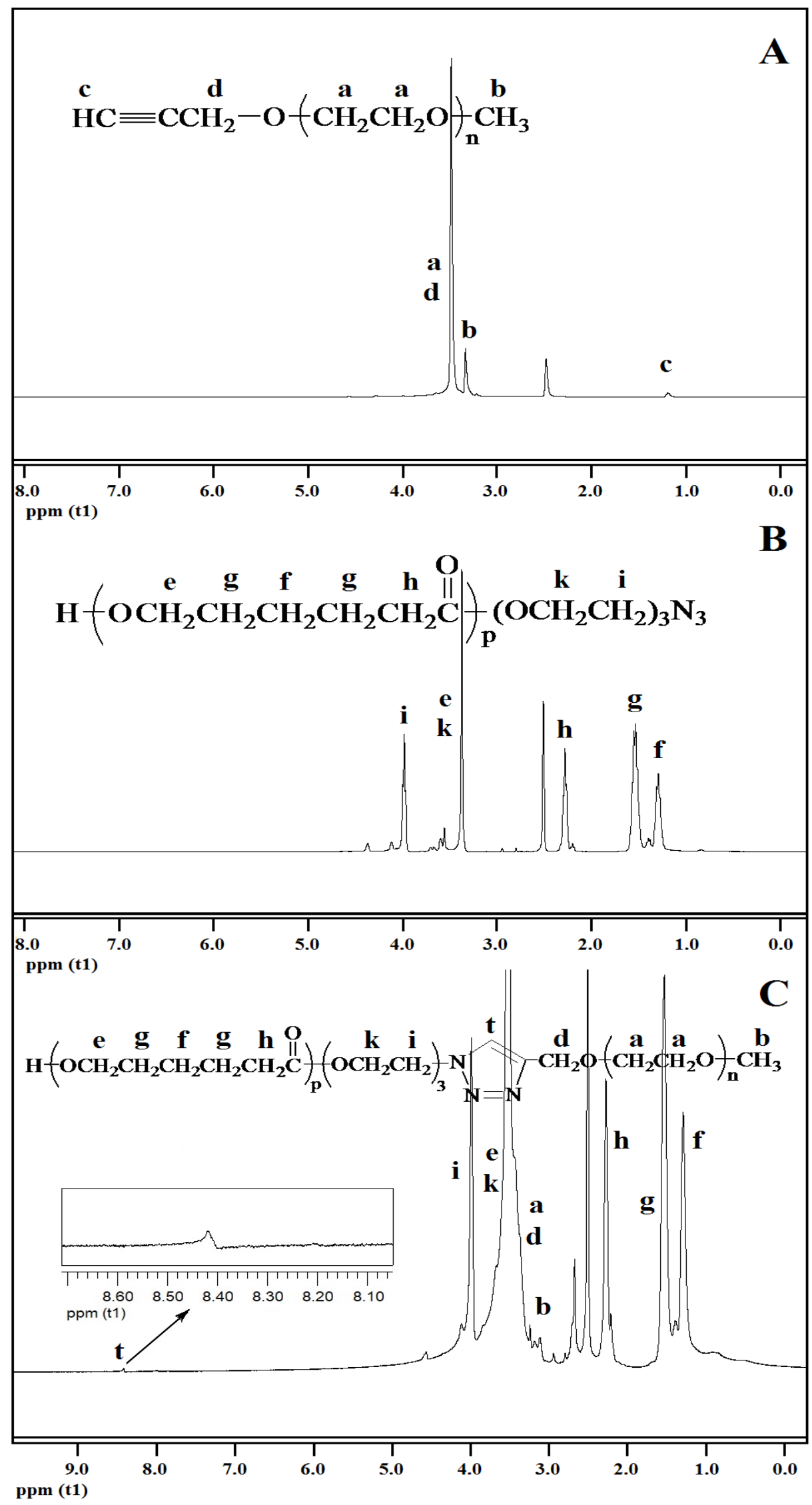

Figure 2. ${ }^{1} \mathrm{H}-\mathrm{NMR}$ of mPEG-propargyl (A), RPCL-N 3 (B), poly(RCL-b-mEG) block copolymer (E-2 in Table 1) (C) (solvent: dimethyl sulfoxide-d $\mathrm{d}_{6}$ ). 

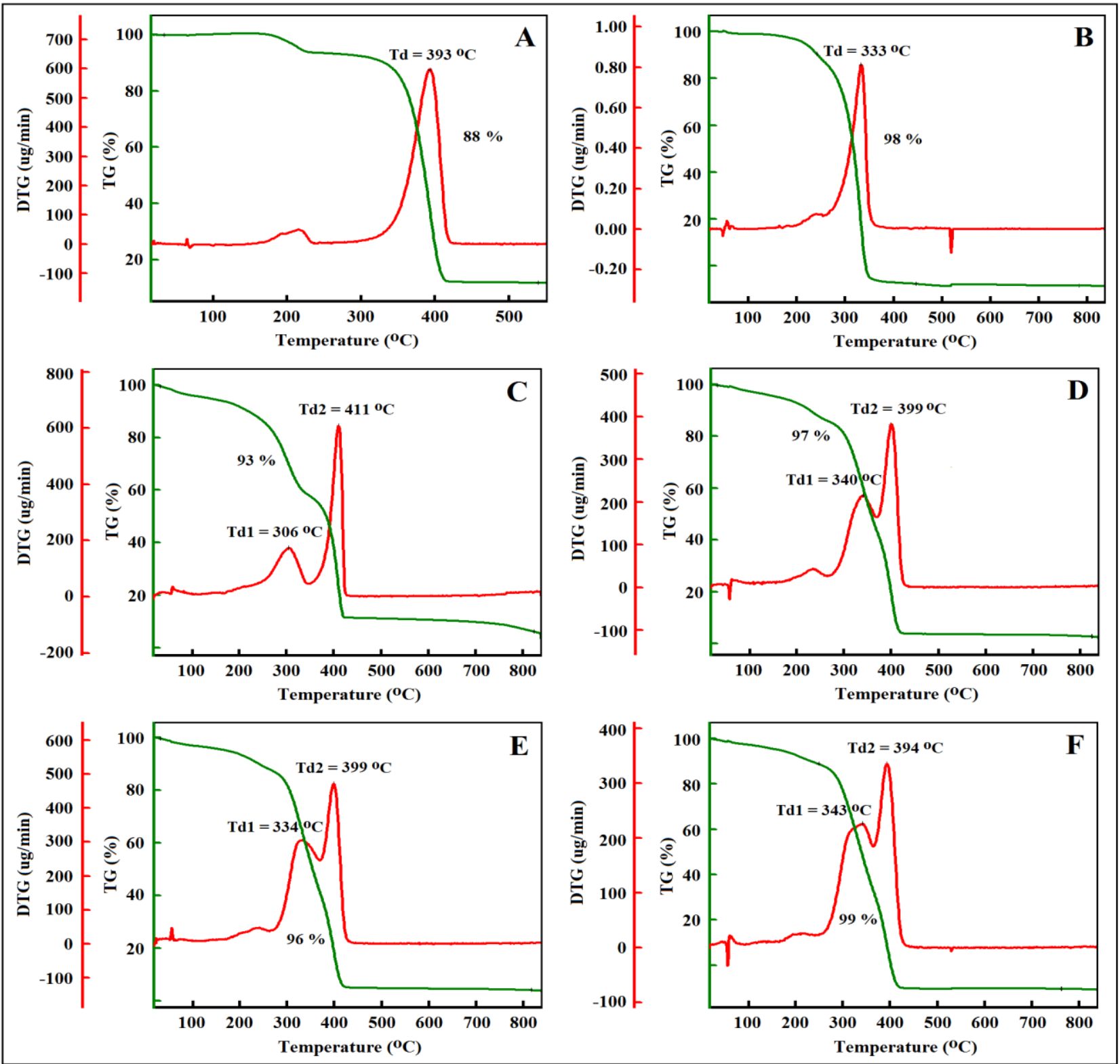

Figure 3. TGA curves of mPEG-propargyl (A), RPCL-N 3 (B), poly(RCL-b-mEG) block copolymer (E-1 in Table 1) (C), poly(RCL-b-mEG) block copolymer (E-2 in Table 1) (D), poly(RCL-b-mEG) block copolymer (E-3 in Table 1) (E), and poly(RCL-b-mEG) block copolymer (E-4 in Table 1) (F).

\section{Synthesis of $\mathbf{N}_{30 l}$}

$\mathrm{N}_{3} \mathrm{Ol}$ as a colorless liquid was synthesized through reaction of 2-[2-(2-chloroethoxy) ethoxy] ethanol and $\mathrm{NaN}_{3}$ (Baker et al., 2013). The reaction outline for $\mathrm{N}_{3}$ ol is shown in Scheme 1 (second line). FT-IR of $\mathrm{N}_{3} \mathrm{Ol}$ in Figure 1.B presented distinctive signals at $3414 \mathrm{~cm}^{-1}$ for $-\mathrm{OH}, 2872 \mathrm{~cm}^{-}$ ${ }^{1}$ for aliphatic $-\mathrm{CH}_{2}, 2106 \mathrm{~cm}^{-1}$ for $-\mathrm{N}_{3}, 1122 \mathrm{~cm}^{-1}$ for -OC. Creation of specific $-\mathrm{N}_{3}$ stretching band at about $2100 \mathrm{~cm}^{-1}$ shows effective azidiation of 2-[2-(2-chloroethoxy)ethoxy]ethanol.

\section{Synthesis of RPCL-N3 by ROP}

RPCL-N $\mathrm{N}_{3}$ was synthesized by starting from $\mathrm{N}_{3} \mathrm{Ol}$ by ROP technique. The reaction pathway is included in Scheme 1 (third line) for RPCL-N ${ }_{3}$. FT-IR of RPCL-N ${ }_{3}$ as shown in Figure 1.C presented distinctive signals at $3440 \mathrm{~cm}^{-1}$ for $-\mathrm{OH}, 2945 \mathrm{~cm}^{-1}$ for aliphatic $-\mathrm{CH}_{2}, 1726 \mathrm{~cm}^{-1}$ for $-\mathrm{C}=\mathrm{O}$. Figure 1.C shows small band feature at about $2099 \mathrm{~cm}^{-1}$ specific for stretching vibration of azide. ${ }^{1} \mathrm{H}-\mathrm{NMR}$ of 
RPCL-N 3 (Figure 2.B) displayed peaks at 4.0 ppm for $-\mathrm{NC}_{2}, 3.4 \mathrm{ppm}$ for $-\mathrm{OC}_{2}, 1.5$ and $1.3 \mathrm{ppm}$ for aliphatic $-\underline{\mathrm{C}}_{2}$. Td value of RPCL-N 3 obtained from TGA was $333^{\circ} \mathrm{C}$ as shown Figure 3.B. GPC curves of RPCL-N 3 were shown in Figure 4. Mw value of RPCL-N 3 was 2,264 Da. Dispersity index of RPCL$\mathrm{N}_{3}$ was 1.43 . The value was relatively narrow.
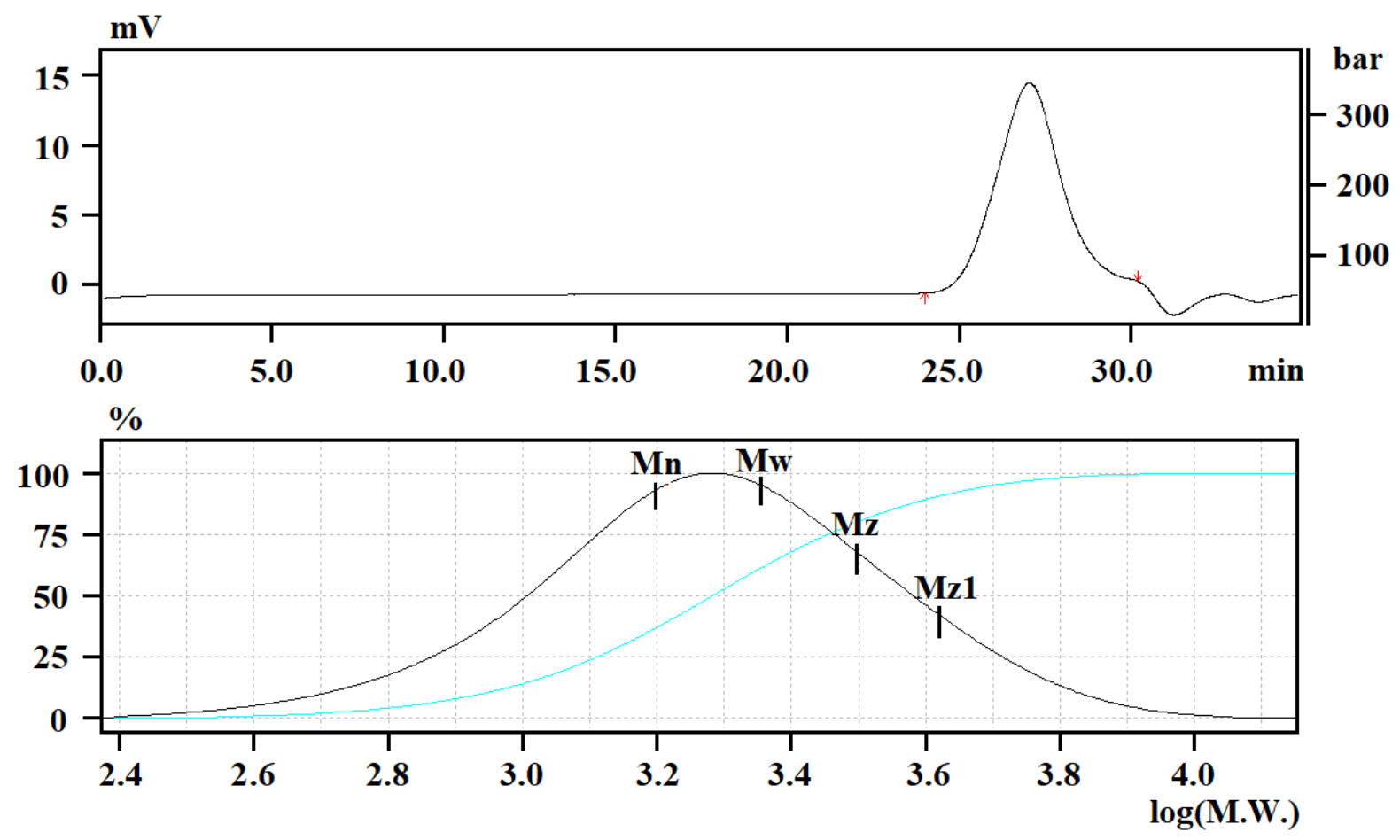

Figure 4. GPC curves of RPCL-N 3 .

\section{Synthesis of poly(RCL-b-mEG) by "click" chemistry}

Poly(RCL-b-mEG) copolymers were obtained at $35{ }^{\circ} \mathrm{C}$ through "click" chemistry of mPEGpropargyl and RPCL-N 3 . Pathway of reaction is included in Scheme 2 for the block copolymers. The yield was between $75.25 \mathrm{wt} \%$ and $93.72 \mathrm{wt} \%$. The FT-IR of poly(RCL-b-mEG) as presented in Figure 1.D presents distinctive signals which belong to the PCL and mPEG-5000 units. Furthermore, the missing of azide $\left(2106 \mathrm{~cm}^{-1}\right)$ and propargyl $\left(3150 \mathrm{~cm}^{-1}\right)$ can be appropriate for "click" reaction between the homopolymers. Records of ${ }^{1} \mathrm{H}-\mathrm{NMR}$ of poly(RCL-b-mEG) block copolymer in Figure 2.C were obtained. ${ }^{1} \mathrm{H}-\mathrm{NMR}$ of poly(RCL-b-mEG) block copolymer displayed peaks at $8.4 \mathrm{ppm}$ for aromatic $\mathrm{C} \underline{\mathrm{H}}$ of triazole, $4.0 \mathrm{ppm}$ for $-\mathrm{NC}_{2}, 3.5 \mathrm{ppm}$ for $-\mathrm{OC}_{2}, 1.5 \mathrm{ppm}$ and $1.2 \mathrm{ppm}$ for aliphatic $-\underline{\mathrm{C}}_{2}$. The signal at $8.4 \mathrm{ppm}$ in the spectrum was regarded as a great evidence for aromatic $-\mathrm{C} \underline{\mathrm{H}}$ of triazole (Lakouraj et al., 2013; Rukmanikrishnan and Muthusamy, 2018; Çatıker, Meyvacı et al., 2019; Öztürk, Meyvacı et al., 2020).

Table 1 shows Td of poly(RCL-b-mEG) block copolymers which were obtained from TGA Figure 3 presents the TGA curves for all block copolymers. In the case of poly(RCL-b-mEG), PCL and PmEG include individual Td. As stated for many copolymers (Jamshid, 2008; Thanomsilp and Phetthianchai, 2012; Çatıker, et al., 2020; Savaş et al., 2020), units in a copolymer show Td as though units are alone. TGA demonstrated fascinating characteristics of copolymer such as continuous weight loss starting from about $200{ }^{\circ} \mathrm{C}$ to nearly $420{ }^{\circ} \mathrm{C}$ with derivatives at $306^{\circ} \mathrm{C}$ and $411^{\circ} \mathrm{C}$ (Figure 3.C). The glass temperature (Tg) value of poly(RCL-b-mEG) block copolymer (E-2 in Table 1) was determined by DSC. Tg value 
was measured as $3{ }^{\circ} \mathrm{C}$ as shown in Figure 5. One main individual Tg of poly(RCL-b-mEG) block copolymer may be relied on high miscibility of mPEG polyether and PCL polyester units of copolymers. $\mathrm{Mw}$ of the block copolymers obtained from dynamic light scattering (DLS) instrument were between 6,510 Da and 10,400 Da. As the amounts of RPCL-N 3 have changed, Mw values of the block copolymers have interestingly also changed (Table 1). The relationship between Mw values of the block copolymers and the amounts of RPCL-N 3 could not observed. The molecular weights of poly(RCL-b-mEG) block copolymers more than the molecular weight values of mPEG-propargyl and RPCL-N 3 could prove the formation of poly(RCL-b-mEG).<smiles>[R17][R17]#N</smiles>

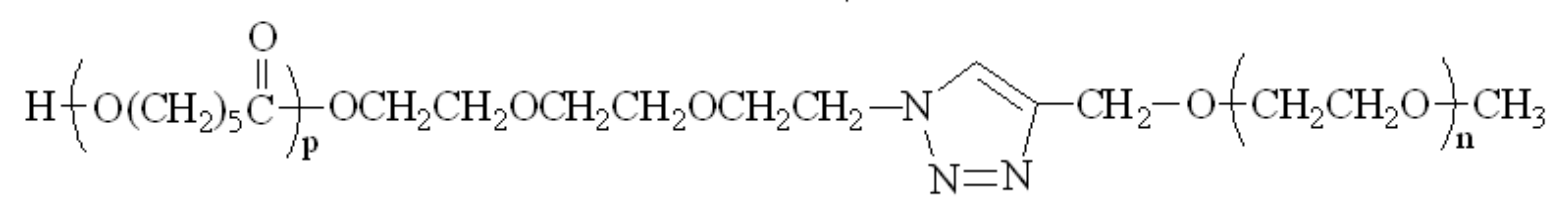

Poly(RCL-b-mEG) block copolymer

Scheme 2. Reaction outline for poly(RCL-b-mEG) copolymer.

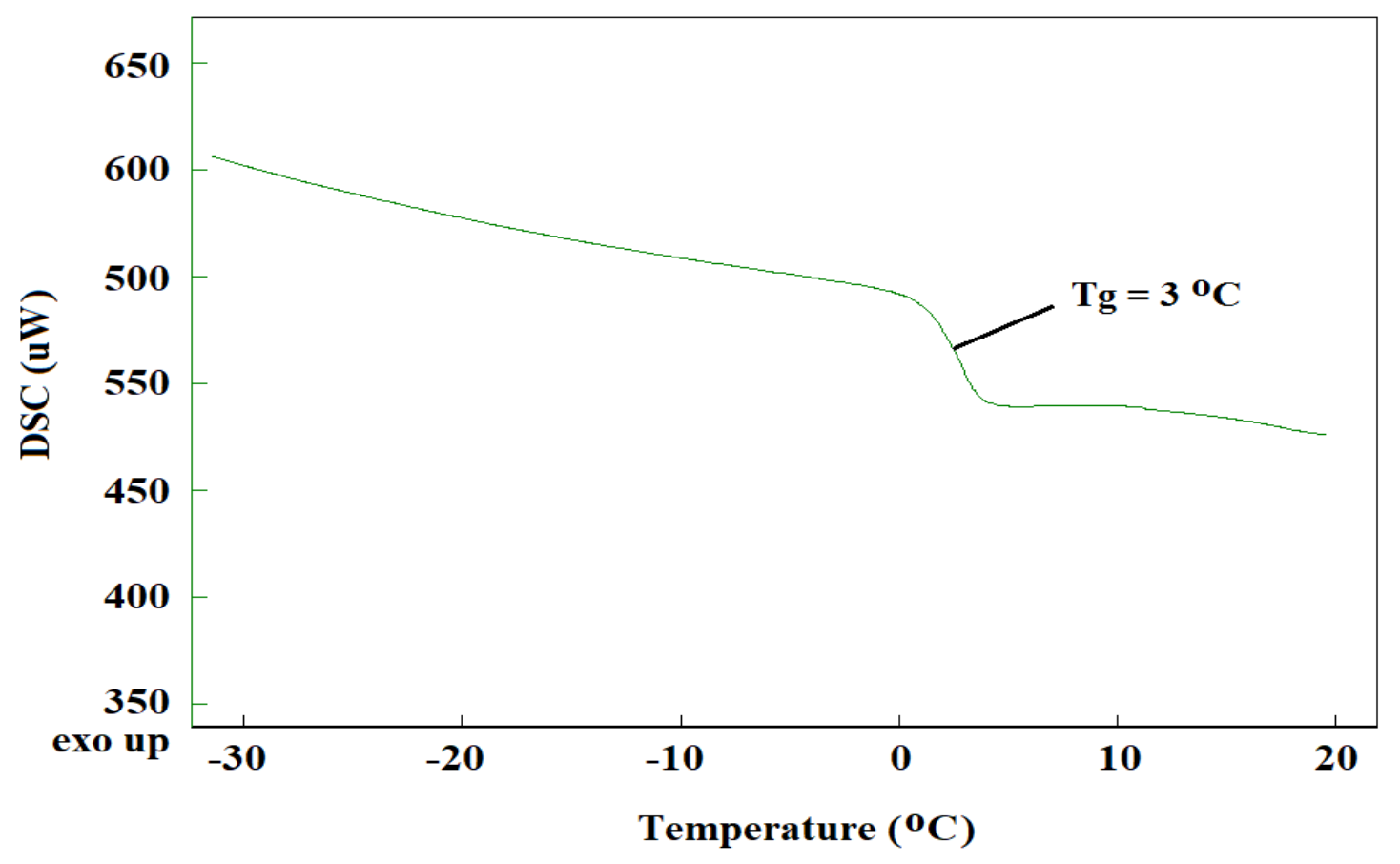

Figure 5. DSC diagram of poly(RCL-b-mEG) (E-2 in Table 1). 
To examine the morphological properties of poly(RCL-b-mEG) block copolymer, SEM device was used. The polymer was coated with a thin layer of gold on its surface. The images were received from different views. The surface morphologies of poly(RCL-b-mEG) block copolymer (E-1 in Table 1) was shown in Figure 6. According to the SEM images of copolymer, homogenization of copolymer was great. By a morphology consisting platelets with channels, the polymer sample was characterized. The rough surfaces which form a continuous phase were recognized.

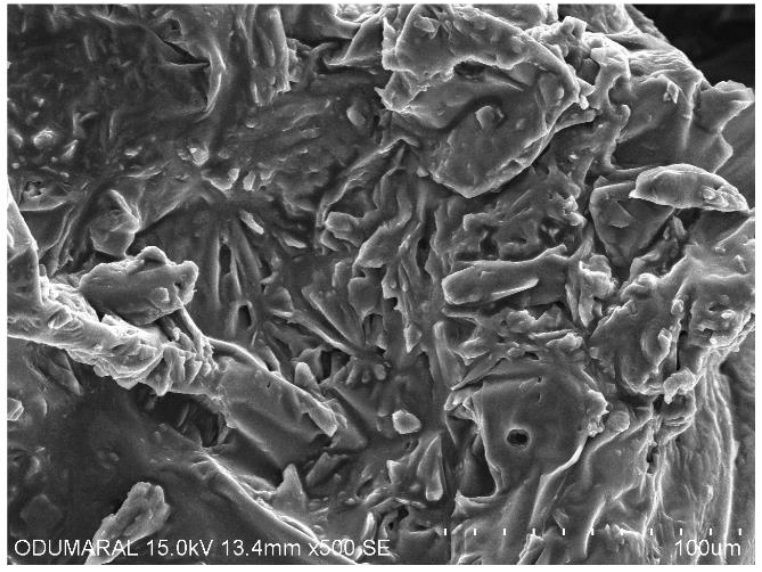

A)

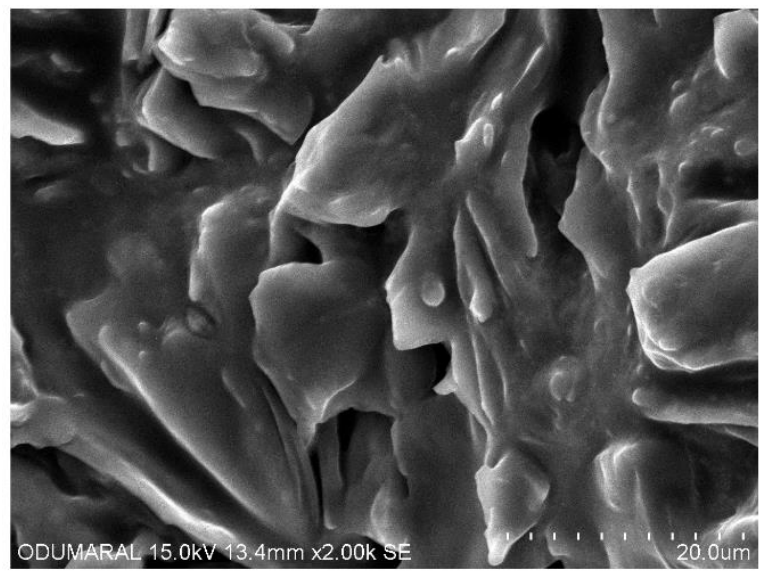

C)

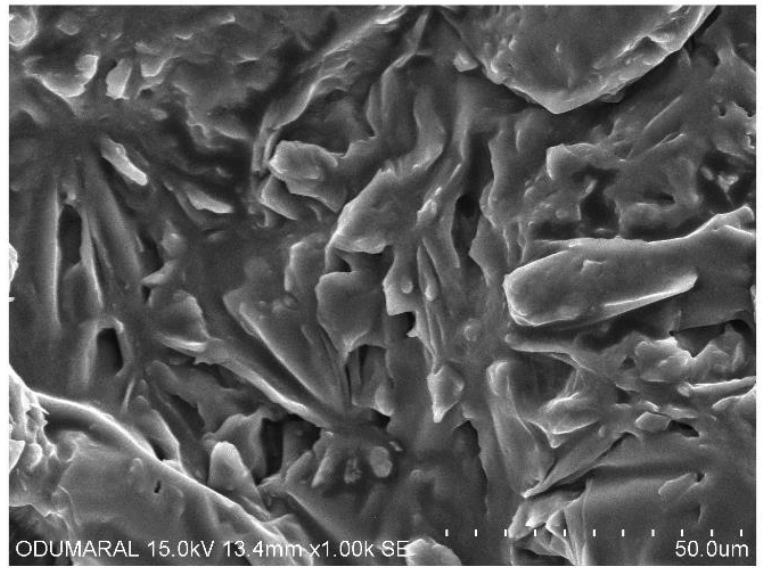

B)

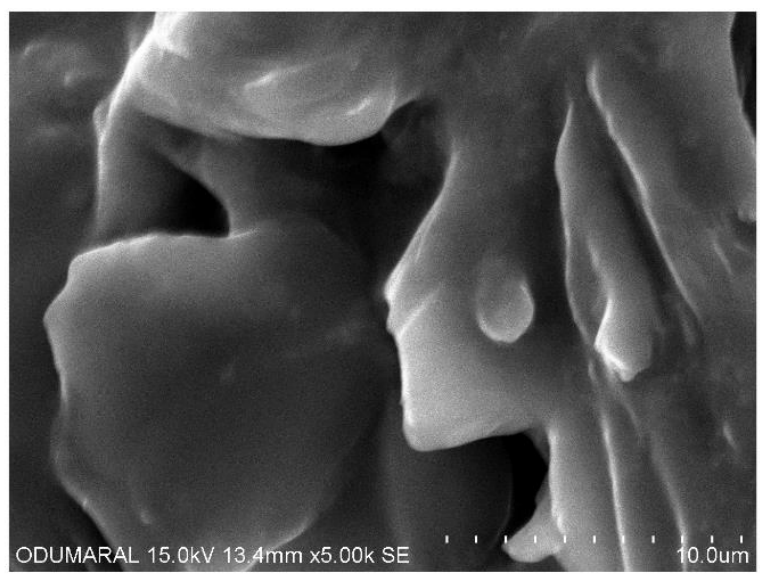

D)

Figure 6. SEM displays of poly(RCL-b-mEG) (coded E-1); $500 \mathrm{X}$ (A), $1000 \mathrm{X}$ (B), $2000 \mathrm{X}$ (C), $5000 \mathrm{X}$ (D).

\section{CONCLUSION}

This work shows synthesis of poly(RCL-b-mEG). This procedure used to synthesize block copolymer is easy and effective. This work can lead the way for further and well-conceived materials used for many applications by means of combination of PCL and mPEG. Product characterization was obtained through ${ }^{1} \mathrm{H}-\mathrm{NMR}$, SEM, FT-IR, TGA, DSC, DLS, GPC analyses.

\section{ACKNOWLEDGEMENTS}

This study was funded by Giresun University Scientific Research Fund (FEN-BAP-C-281119-76).

\section{Conflict of Interest}

The article authors declare that there is no conflict of interest between them. 


\section{Author's Contilbutions}

The authors declare that they have contributed equally to the article.

\section{REFERENCES}

Adams ML, Lavasanifar A, Kwon GS, 2003. Amphiphilic block copolymers for drug delivery. Journal of Pharmaceutical Sciences, 92 (7): 1343-1355.

Altintas O, Tunca U, Barner-Kowollik C, 2011. Star and miktoarm star block (co)polymers via selfassembly of ATRP generated polymer segments featuring Hamilton wedge and cyanuric acid binding motifs. Polymer Chemistry, 2 (5): 1146-1155.

Altıntas O, Tunca U, 2011. Synthesis of terpolymers by click reactions. Chemistry - An Asian Journal, 6 (10): 2584-2591.

Bağlan M, Yıldıko Ü, Çakmak İ, Tekeş AT, 2018. Synthesis of PMMA-b-PEG-b-PMMA by controlled Polymerization Using Macro-RAFT Agents. Journal of the Institute of Science and Technology, 8 (3): 243 254

Baker YR, Galloway WRJD, Hodgkinson JT, Spring DR, 2013. Design and synthesis of a biotinylated chemical probe for detecting the molecular targets of an inhibitor of the production of the pseudomonas aeruginosa virulence factor pyocyanin. Molecules, 18 (10): 11783-11796.

Barner-Kowollik C, Du Prez FE, Espeel P, Hawker CJ, Junkers T, Schlaad H, Camp WV, 2011. "Clicking" polymers or just efficient linking: what is the difference? Angewandte Chemie International Edition, 50 (1): 60-62.

Binder WH, Sachsenhofer, R, 2007. "Click" chemistry in polymer and materials science. Macromolecular Rapid Communications, 28 (1): 15-54.

Bolton J, Rzayev J, 2012. Tandem RAFT-ATRP synthesis of polystyrene-poly(methyl methacrylate) bottlebrush block copolymers and their self-assembly into cylindrical nanostructures. ACS Macro Letters, 1 (1): 15-18.

Çatıker E, Öztürk T, Atakay M, Salih B, 2020. Synthesis and characterization of the ABA-type poly(ester-etherester) block copolymers. Journal of Macromolecular Science, Part A: Pure and Applied Chemistry, 57 (8): 600-609.

Çatıker E, Öztürk T, Atakay M, Salih B, 2019. Synthesis and characterization of novel ABA type poly(esterether) triblock copolymers. Journal of Polymer Research, 26 (5): 123.

Çatıker E, Meyvacı E, Atakay M, Salih B, Öztürk, T, 2019. Synthesis and characterization of amphiphilic triblock copolymers including $\beta$-alanine/ $\alpha$-methyl- $\beta$-alanine and ethylene glycol by "click" chemistry. Polymer Bulletin, 76 (4): 2113-2128.

Coulembier O, Degee P, Hedrick JL, Dubois P, 2006. From controlled ring-opening polymerization to biodegradable aliphatic polyester: especially poly(beta-malic acid) derivatives. Progress in Polymer Science, 31 (8): 723-747.

Erciyes AT, Erim M, Hazer B, Yağcı Y, 1992. Synthesis of polyacrylamide flocculants with poly(ethylene glycol) segments by redox polymerization. Die Angewandte Makromolekulare Chemie, 200 (1): 163-171.

Gacal B, Durmaz H, Tasdelen MA, Hizal G, Tunca U, Yagci Y, Demirel AL, 2006. Anthracene-maleimide-based Diels-Alder "click chemistry" as a novel route to graft copolymers. Macromolecules, 39 (16): 5330-5336.

Göktaş M, Öztürk T, Atalar MN, Tekeş AT, Hazer B, 2014. One-step synthesis of triblock copolymers via simultaneous reversible-addition fragmentation chain transfer (RAFT) and ring-opening polymerization using a novel difunctional macro-RAFT agent based on polyethylene glycol. Journal of Macromolecular Science, Part A: Pure and Applied Chemistry, 51 (11): 854-863.

Hizal G, Sakar D, Tunca U, 2005. Synthesis of tri-arm star di-block co-polymer containing poly(tetrahydrofuranb-methyl methacrylate) arms via combination of cationic ring-opening polymerization and photosensitized free radical polymerization routes. Designed Monomers and Polymers, 8 (6): 609-617.

Jamshid MR, 2008. Synthesis and thermal properties of novel multiblock biodegradable copolymers derived from polyethylene glycol, $\varepsilon$-caprolactone and p-dioxanone. ScienceAsia, 34 (2): 207-213. 
Kolb HC, Finn MG, Sharpless KB, 2001. Click chemistry: diverse chemical function from a few good reactions. Angewandte Chemie International Edition, 40 (11): 2004-2021.

Lakouraj MM, Hasantabar V, Bagheri N, 2013. Synthesis of polyethers containing triazole units in the backbone by click chemistry in a tricomponent reaction. Journal of Polymers, 2013, 167106.

Öztürk T, Hazer B, 2010. Synthesis and characterization of a novel macromonomer initiator for reversible addition fragmentation chain transfer (RAFT). Evaluation of the polymerization kinetics and gelation behaviors. Journal of Macromolecular Science, Part A: Pure and Applied Chemistry, 47 (3): 265-272.

Öztürk T, Savaş B, Meyvacı E, Kılıçlıoğlu A, Hazer B, 2020. Synthesis and characterization of the block copolymers using the novel bifunctional initiator by RAFT and FRP technics: evaluation of the primary polymerization parameters. Journal of Polymer Research, 27 (3): 76.

Öztürk T, Kayğın O, Göktaş M, Hazer B, 2016. Synthesis and characterization of graft copolymers based on polyepichlorohydrin via reversible addition-fragmentation chain transfer polymerization. Journal of Macromolecular Science, Part A: Pure and Applied Chemistry, 53 (6): 362-367.

Öztürk T, Göktaş M, Hazer B, 2011. Synthesis and characterization of poly(methyl methacrylate-block-ethylene glycol-block-methyl methacrylate) block copolymers by reversible addition-fragmentation chain transfer polymerization. Journal of Macromolecular Science, Part A: Pure and Applied Chemistry, 48 (1): 65-70.

Öztürk S, Cakmak İ, Tekeş AT, Yıldıko Ü, 2019. Synthesis and Characterization of Poly (lactic acid-b- $\varepsilon-$ caprolactone) Block Copolymers. Journal of the Institute of Science and Technology, 9 (2): 1035-1045.

Öztürk T, K1lıçlıoğlu A, Savaş B, Hazer B, 2018. Synthesis and characterization poly( $\varepsilon$-caprolactone-co-ethylene glycol) heteroarm star-type amphiphilic copolymers by "click" chemistry and ring-opening polymerization. Journal of Macromolecular Science, Part A: Pure and Applied Chemistry, 55 (8): 588-594.

Öztürk T, Yavuz M, Göktaş M, Hazer B, 2016. One-step synthesis of triarm block copolymers by simultaneous atom transfer radical and ring-opening polymerization. Polymer Bulletin, 73 (6): 1497-1513.

Öztürk T, Meyvac1 E, 2017. Synthesis and characterization poly(e-caprolactone-b-ethylene glycol-b- $\varepsilon$ caprolactone) block copolymers via "click" chemistry and ring-opening polymerization. Journal of Macromolecular Science, Part A: Pure and Applied Chemistry, 54 (9): 575-581.

Öztürk T, Meyvacı E, Bektaş H, Menteşe E, 2019. Synthesis and characterization of ring-type and branched polymers including polyethylene glycols by "click" chemistry, SN Applied Sciences, 1 (4): 343.

Öztürk T, Meyvac1 E, Arslan T, 2020. Synthesis and characterization of poly(vinyl chloride-g-e-caprolactone) brush type graft copolymers by ring opening polymerization and "click" chemistry. J Macromol Sci Part A, 57 (3): 171-180.

Öztürk T, Yörümez C, 2020. Synthesis of block copolymer including polyepichlorohydrin and polyethylene glycol by "click" chemistry: evaluation of primary parameters of copolymerization. Polymer Bulletin, 77, 4773-4788.

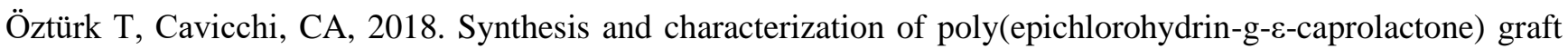
copolymers by "click" chemistry. Journal of Polymer Materials, 35 (2): 209-220.

Moses JE, Moorhouse AD, 2007. The growing applications of click chemistry. Chemical Society Reviews, 36 (8): $1249-1262$.

Riess G, 2003. Micellization of block copolymers. Progress in Polymer Science, 28 (7):1107-1170.

Rukmanikrishnan B, Muthusamy S, 2018. Preparation and properties of polyimides containing 1,2,3-triazole moieties. Advances in Polymer Technology, 37 (1): 21641.

Ruzette AV, Leibler L, 2005. Block copolymers in tomorrow's plastics. Nature Materials, 4 (1): 19-31.

Şanal T, Koçak İ, Hazer B, 2017. Synthesis of comb-type amphiphilic graft copolymers derived from chlorinated poly( $\varepsilon$-caprolactone) via click reaction. Polymer Bulletin, 74 (4): 977-995.

Savaş B, Öztürk T, Meyvacı E, Hazer B, 2020. Synthesis and characterization of comb-type graft copolymers by redox polymerization and "click" chemistry method. SN Applied Sciences, 2 (2): 181.

Thanomsilp C, Phetthianchai U, 2012. Synthesis and characterization of PLA-co-PEG copolymers. Advanced Materials Research, 506, 178-181. 
Tunca U, 2018. Click and multicomponent reactions work together for polymer chemistry. Macromolecular Chemistry and Physics, 219 (16): 1800163.

Tunca, U, 2013. Triple click reaction strategy for macromolecular diversity. Macromolecular Rapid Communications, 34 (1): 38-46.

Zhu DY, Cao GS, Qiu WL, Rong MZ, Zhang MQ, 2015. Self-healing polyvinyl chloride (PVC) based on microencapsulated nucleophilic thiol-click chemistry. Polymer, 69, 1-9.

Xu J, Ye J, Liu SY, 2007. Synthesis of well-defined cyclic poly(N-isopropylacrylamide) via click chemistry and its unique thermal phase transition behavior. Macromolecules, 40 (25): 9103-9110.

Xi W, Scott TF, Kloxin CJ, Bowman CN, 2014. Click chemistry in materials science. Advanced Functional Materials, 24 (18): 2572-2590. 